\title{
O estado da habitação em Portugal: Uma trajetória promissora mas ainda excessivamente em aberto
}

\author{
João Ferrão, Instituto de Ciências Sociais da Universidade de Lisboa, Portugal.
}

Quando, em 2014, Marco Allegra e a sua equipa começaram a preparar a candidatura do projeto exPERts a um concurso de apoio à investigação da Fundação para a Ciência e a Tecnologia, estavam certamente longe de imaginar que o tema da habitação iria ocupar, muito em breve, um lugar central na agenda política portuguesa.

Os temas de investigação, como muitos outros aspetos da vida coletiva, têm modas, caracterizando-se pela alternância entre momentos de interesse e fulgor e outros de relativa marginalização ou quase esquecimento. Claro que há fatores, internos à própria academia mas sobretudo relacionados com a evolução das sociedades e das economias, que permitem compreender esses vários ciclos de emergência, apogeu e ocaso de determinados temas. E também é certo que a proposta inicial do projeto exPERts não tinha como objeto a questão genérica da habitação, mas sim um foco mais restrito e específico: o papel dos peritos nas políticas públicas através da análise do Programa Especial de Realojamento (PER). A verdade é que, num misto de intuição informada, ocorrência de circunstâncias não previstas, sentido de oportunidade e capacidade de leitura sistémica da situação, o projeto e a equipa colocaram-se no centro de um debate vivo e crescentemente alargado de um tema recorrente na história da sociedade portuguesa, mas intermitente na história da produção científica nacional.

A chamada questão da habitação, no seu sentido mais amplo, é, aliás, um espelho privilegiado das relações que ao longo do tempo se estabelecem entre as esferas política, económica e social, refletindo a evolução de opções políticas, dinâmicas económicas e reconfigurações sociodemográficas, bem como as inevitáveis tensões e conflitos que sucessivamente se vão gerando entre interesses, valores, necessidades, prioridades e soluções divergentes, contraditórios ou mesmo antagónicos.

A questão da habitação está pois, de novo, no centro dos debates político e público, das agendas académica e mediática, das políticas públicas e dos movimentos ativistas. Contudo, o regresso de um tema ao centro das controvérsias e dos palcos de decisão, ação e confronto não é, evidentemente, uma mera reemergência: com o passar do tempo, mudaram os contextos ao nível internacional e nacional, modificaram-se os atores em presença e as relações de poder entre eles, alteraram-se as perspetivas analíticas e metodológicas. Mas reemergir significa também que existe um passado e um legado que não desapareceram: problemas e dinâmicas recorrentes ganham agora uma nova visibilidade e 'velhos` princípios e direitos são resgatados, permitindo retirar partido de ciclos de debate e intervenção anteriores.

A 'questão da habitação` é pois uma questão renovada, não uma nova questão: ela nunca desapareceu, ela aliás esteve sempre bem presente do lado dos perdedores e dos seus apoiantes. Mas renasce hoje aos olhos de todos como algo demasiado relevante para que possa ser ignorado ou considerado como um problema menor, uma disfunção setorial e geograficamente localizada, uma questão em vias de solução através de mecanismos de mercado eficazes e de políticas públicas de habitação eficientes.

Os artigos e as entrevistas incluídos neste número temático da revista Cidades. Comunidades e Territórios constituem um sólido contributo para um novo ciclo de debate e de intervenção política que tenha a questão da habitação no seu centro, mas que olhe para ela a partir de um enquadramento mais amplo e enriquecido. Em suma, como um problema estrutural, cuja genealogia é necessário conhecer, a exigir reformas estruturais, para as quais urge construir bases adequadas e duradouras.

O estado da habitação que aqui é apresentado privilegia, inevitavelmente, determinados eixos de análise e domínios de proposta, com destaque para as dinâmicas do mercado de habitação num contexto de crescente 
gentrificação, "turistificação" e financeirização, para a relação entre ação pública e mercado em termos de regulação, financiamento e provisão de habitação, e para o papel dos mecanismos de governança, do tipo de conhecimento mobilizado, da aprendizagem e capacitação institucional, do debate público, das práticas de participação cidadã, da experimentação e do enquadramento legal no desenho e concretização de políticas de habitação e planeamento urbano eficientes, democráticas e justas.

O desafio é enorme. A ambição também. Este número temático é, portanto, um bom ponto de partida para um debate sério e ousado sobre o que queremos e o que não queremos quando falamos de habitação como um direito social num contexto de crescente financeirização, globalização e coalescência dos mercados, de que o fundiário, o da construção, o imobiliário e o habitacional representam uma parte muito relevante pelo modo como interferem no quotidiano dos cidadãos, mas também pela diversidade de interesses privados e públicos a eles associados. Este é o repto que os autores e as entrevistadas nos deixam. Esta é a caminhada que o número temático prossegue, retirando partido do legado deixado por outros ao mesmo tempo que nos convoca para a construção de um percurso que tem recebido contributos muito relevantes desde 2017, mas cuja trajetória futura se mantém excessivamente em aberto.

Copyright $\odot 2019$ (Ferrão, J.)

Licensed under the Creative Commons Attribution Non-commercial No Derivatives. 